\title{
Analyzing the Role of Basic Religion Institutions in the Local Community Development: The Case of Sheshgelan Neighborhood
}

\author{
Peyman Zadehbagheri* \\ PhD in Islamic Urbanism, University Instructor and Urban Planner, Yasuj, Iran. \\ (Received 23 Sept 2020, Accepted 4 Jan 2021)
}

Religious institutions are a group of social institutions that aim to meet the religious needs of society. A religious institution that has an active presence in Islamic societies is the mosque. Mosque, as the main building in Islamic cities, serves two main purposes. Religious purpose: it means the worship of God collectively and social purpose: it means creating unity within the community and reinforcement of social relations. The purpose of this study is to identify the role that religious institutions, especially mosques, can play in the development of local communities. Research adopts a descriptive-analytical approach. In the theoretical framework and literature of the subject, the documentary method has been used and the research findings have been collected using the field method and preparing a questionnaire. The statistical population of the present study includes the residents of Sheshgelan neighborhood in District 10 of Tabriz Municipality. Shashgelan is one of the few neighborhoods that has 6 active mosques, and the service area of some of these mosques includes the whole city of Tabriz. Existence of a network of effective communication between the residents of the neighborhood with a sense of sharing interests has turned Sheshgelan into a developing neighborhood community. But what has been neglected in the meantime is the role that the related mosques can play in the development of the local community. The Cochran's formula has been used to obtain the sample size. Based on this and according to the statistical population, the sample size includes 150 people and the unit of analysis in this study is indi- vidual. The research hypothesis is based on the fact that there is a significant relationship between religious institutions and the development of local communities. Kendall coefficient and Spearman correlation coefficient were used to determine this relationship. Results of the research show that the value of the Kendall coefficient among all components of local community development and religious institutions is above $60 \%$ and the Spearman correlation coefficient exceeds $65 \%$, which indicates a positive and significant relationship between components of local community development and its religious institution. Findings show that daily interaction in the mosques of Sheshgelan neighborhood leads to the formation of a sense of trust that is effective in restoring trust and continuity of interaction. The neighborhood mosque is a place of gathering and a basis for unity and solidarity of different strata of the neighborhood residents. The neighborhood mosque can even be considered as a council mosque and a representative of the Muslim community in the neighborhood, and this social unit with principled planning can have a tremendous impact on advancing the neighborhood development and solving its problems. Also, the mosque plays a great role in creating harmony and empathy and creating social interactions among the residents of the neighborhoods, to provide a work space and interaction at the neighborhood level.

Keywords: Religious institutions, local community development, Sheshgelan neighborhood.

\footnotetext{
${ }^{*}$ Corresponding author. E-mail: pzadehbagheri@gmail.com
} 


\title{
واكاوى نقش نهادهاى مذهب يايه در توسعةُ اجتماع محلهاى
} نمونة موردى: محلة ششَّألان

\author{
"يبمان زاده باقرى" \\ دكتراى شهرسازى اسلامى، مدرس دانشكاه و برنامهريز شهرى، ياسورج، ايران.

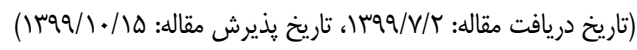

نهادهاى مذهبى، كروهى از نهادهاى اجتماعى هستند كه هدفشان بر آورده ساختن نيازهـاى دينسى و مــهبى جامعـه.

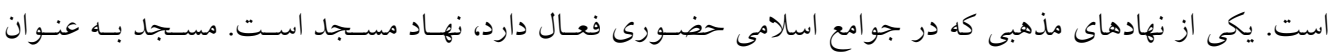
اصلى ترين بنا در شهرهاى اسلامى، دو هدف عمده دارد. هدف مذهبى: يعنى برسـتش و عبـادت خــدا بـه صـورت

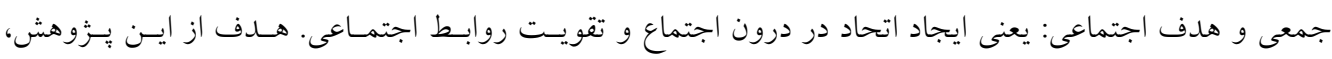
شناسايى نقشى است كه نهادهاى مذهبى و بهويزه مساجد مسى توانتـا در توسـعة اجتماعـات محلسى داشـته باشـند.

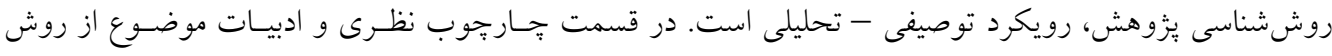

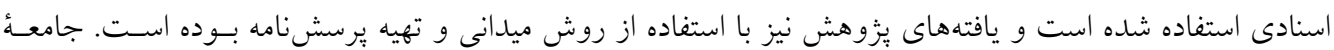

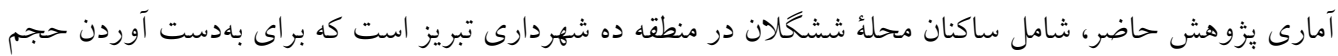

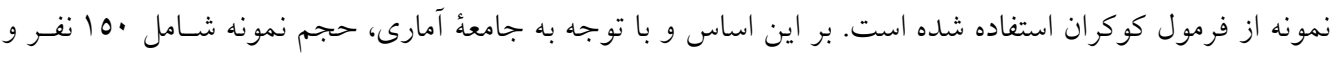

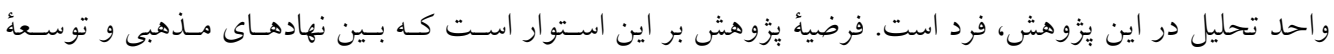

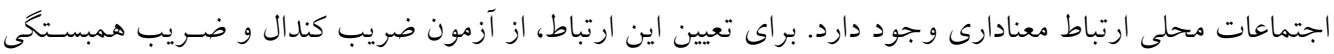

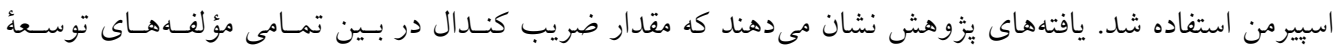

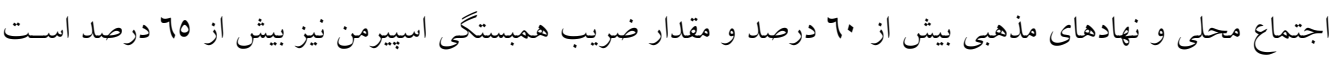
كه اين امر بيانخر رابطؤ مثبت و معنادارى ميان مؤلفهاى توسعة اجتماع محلى و نهادهاى مذهبى است. 
هزار نفر، يكى مسجد در ايران وجود دارد كه بـه ايـن ترتيـب

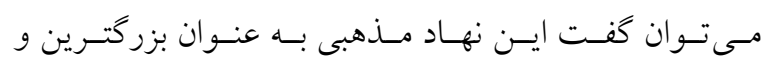

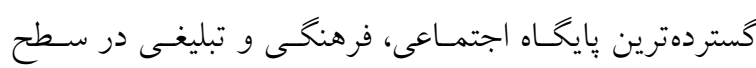

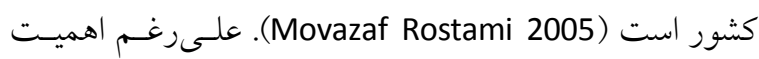

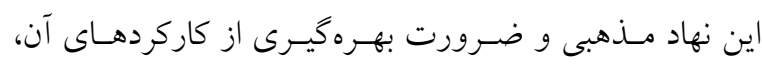

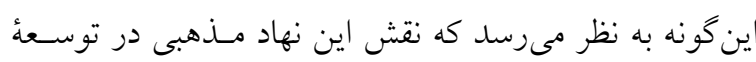
اجتماع محلهاى كمتر مورد توجه قرار كرفته است. محلة ششخحلان در منطقة ده شهردارى تبريـز، از محــدود محلاتى است كه شش مسـجد فعـال در سطعح محلـه دارد و حوزه خدماتدهى برخى از اين مساجد تمامى شهر تبريـز را

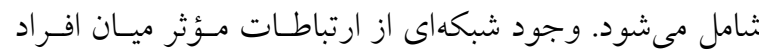

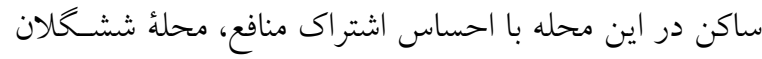
را به يكى اجتماع محلهاى در حال توسعه تبديل كرده اسـت. اما جيزى كه در اين بين، مغفول مانده است توجـه بـهـ ميـزان

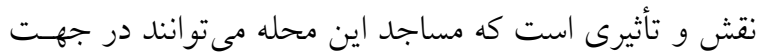
توسعة اجتماع در محلة ششخلان داشته باشند.

در جاهـايى كـه افـراد بيشـتر در مســاجد حضـور داشـتند،

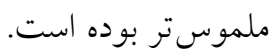

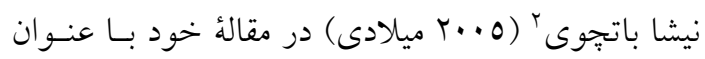

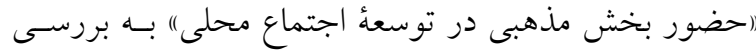

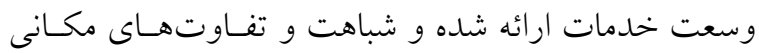

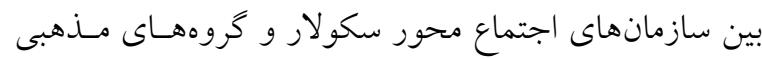

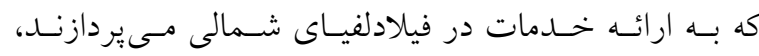

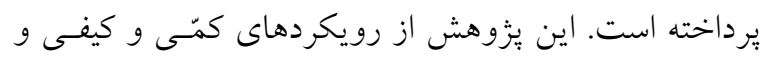

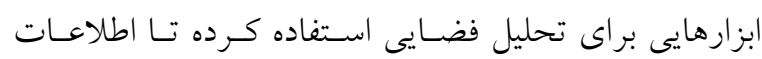

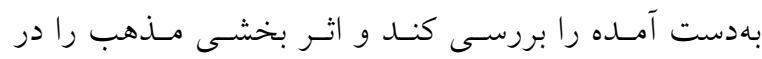

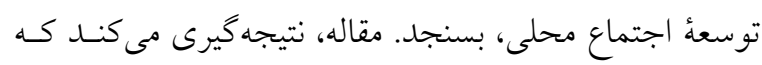

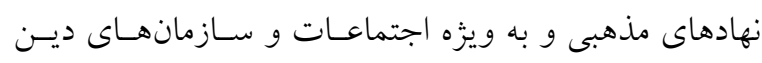
محور، حضور اجتماعى مهمى در خدماترسانى دارند و در

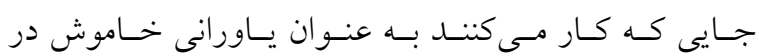

توسعd اجتماع محلهاى به عنوان تلاشى برنامهريزى شده براى

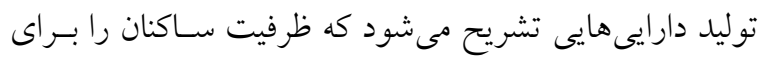

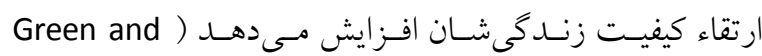

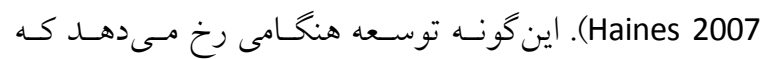

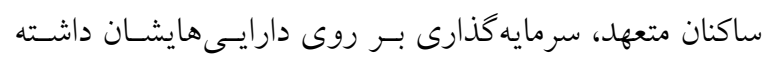

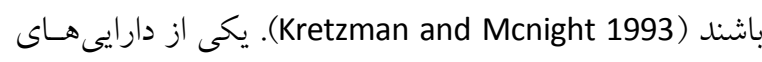

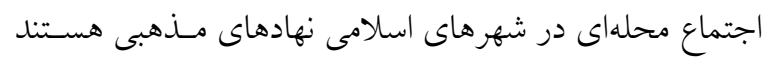

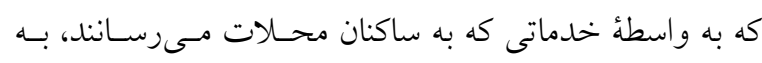
عنـوان يـاورانى خـاموش عمـل مسى كنتـــ (Sullivan 1998). مسجد به عنوان مهمترين نهاد مـذهبى در محسلات شهرهاى اسلامى، نهادى است فعال، اثركذار، مسئوليتيذير در صـنهأ

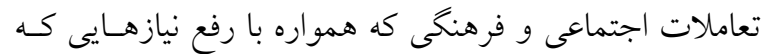

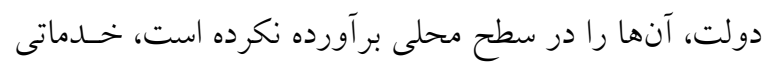

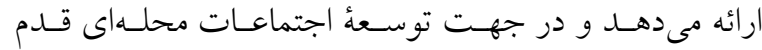

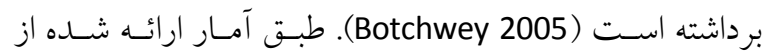

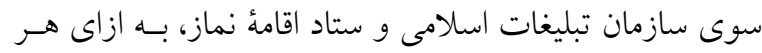

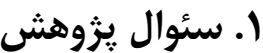

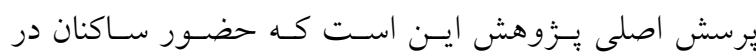

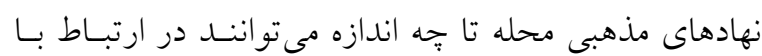
توسعة اجتماعات محلهاى نقش آفرينى كنند؟

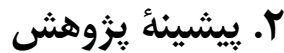

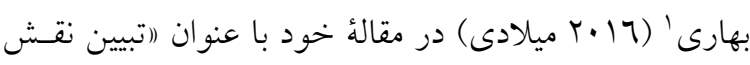

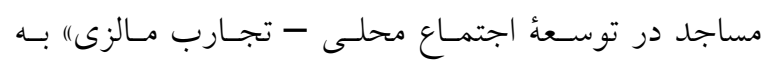

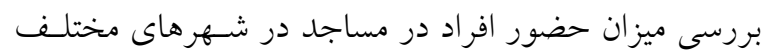

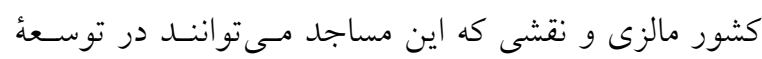

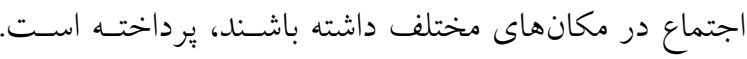
نتايج يزوهش نشان مى دهند كه رابطؤ مستقيمى بـين ميـزان حضور افراد محلى در مسجد با توسعة اجتماع محلى وجود

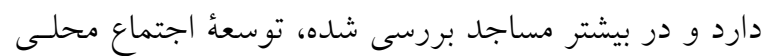


واكاوى نقش نهادهاى مذهب بايه در توسعل اجتماع محلهاى

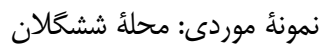

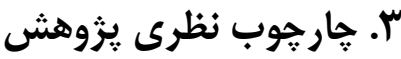 انكَاشت نهاد مذهبى}

نهادهاى اجتماعى مهمترين سازمانهاى اجتماعى هستـند كـهـ

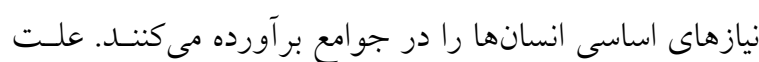

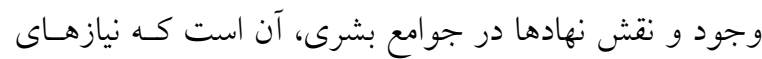

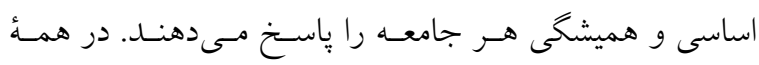

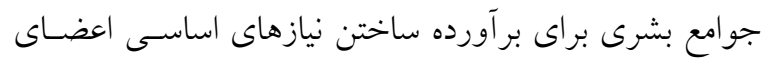

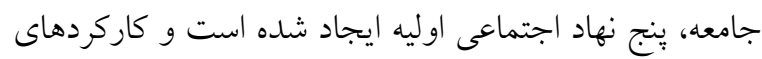

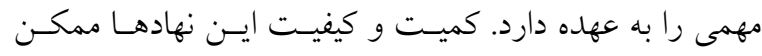

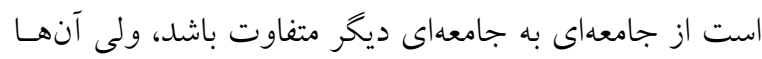

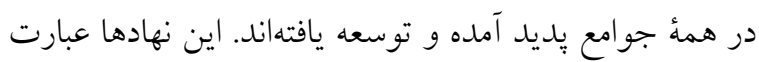

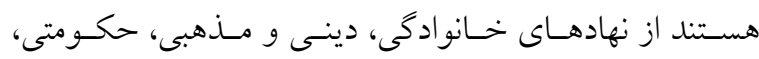

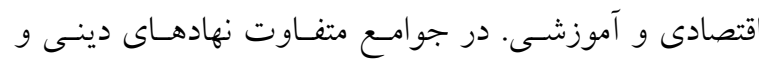

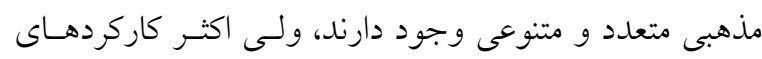

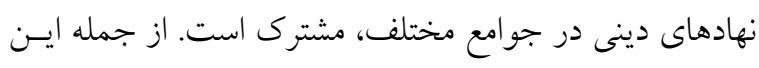

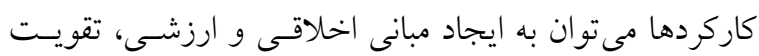

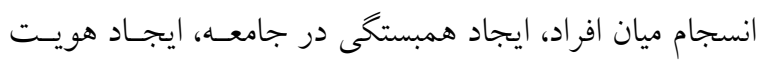
اخلاقى، تقويت ارزشهاى انسانى و توجه دادن بـه انسـانهـا

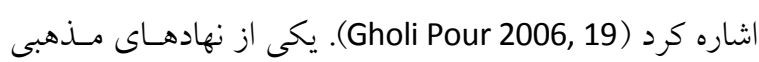
كه در جوامع اسلامى حضورى فعال دارد، نهاد مسجد است. مسـجد در عــرف و فرهنـع اســامى بــه عبادتخـاه

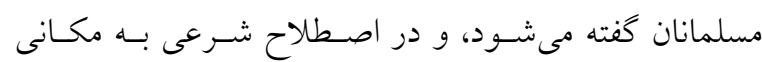

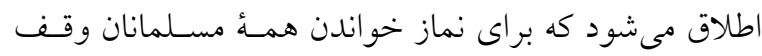

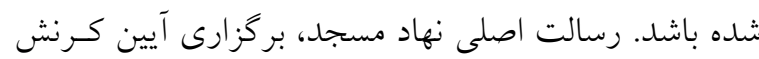

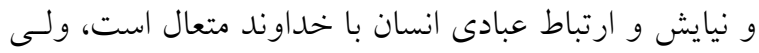

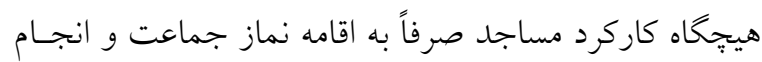
عبادات جمعى محدود نشده است. جدول شمارة أكـاركرد مساجد را در ادوار مختلف نشان مىدهد.

\section{انغَاشت اجتماع و اجتماع محلى}

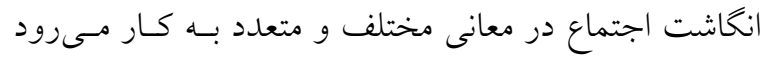

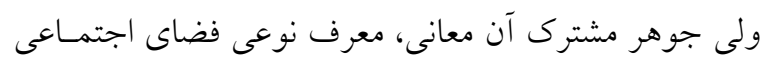

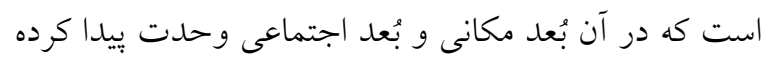
است. اين مفهومى است كه از نظر برنامهريزى شهرى بسيار

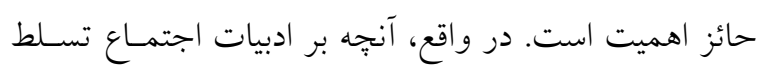

خدماترسانى به افراد اهميت حياتى دارند و بـراى توسـعة

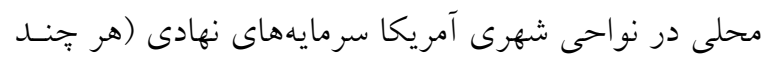

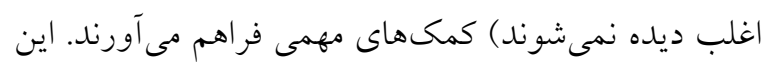

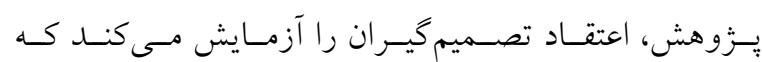

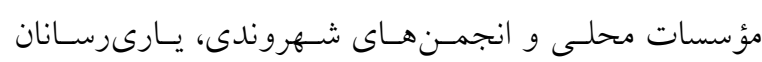

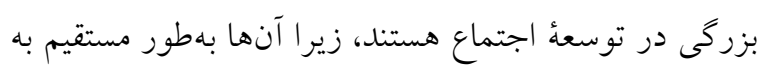
نيازمندان كمك مى كنند.

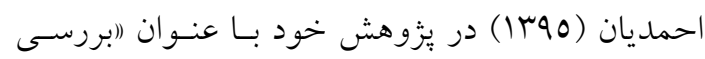

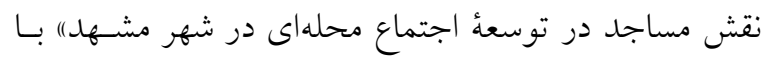

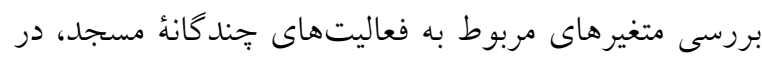

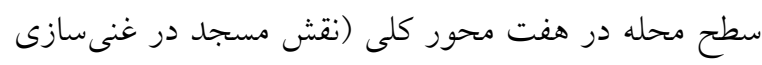

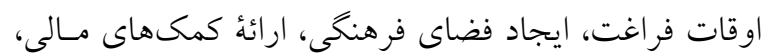

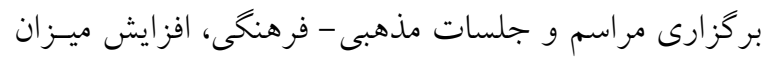

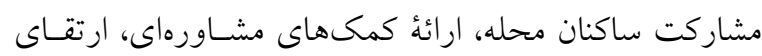

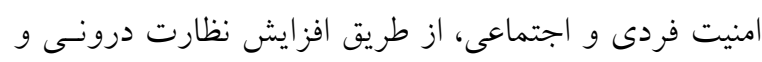

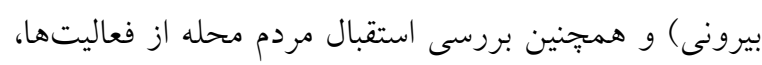

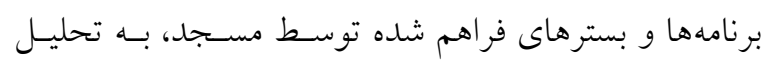

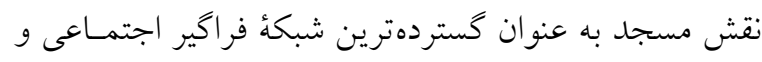
نقش آفرينى آن در توسعة محلهاى در شهر مشهد مى يسردازد.

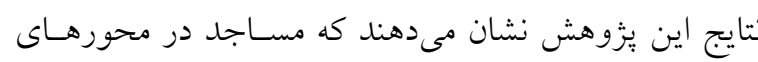

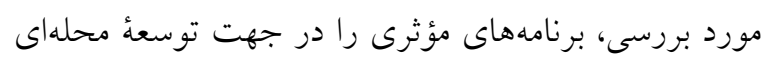
دارند. - مار.

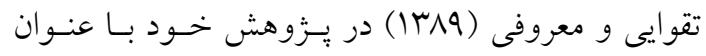
(ارزيـابى نقـش مسـاجد در ارتقــاء كيفيـت محسيط، مطالعـهُ

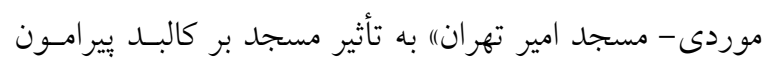

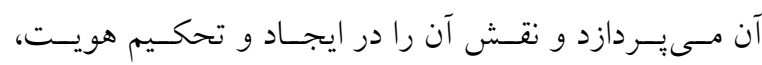
خوانايى، معنابخشى و جهـت دهـى بـه محسيط كالبـدى مـؤثر

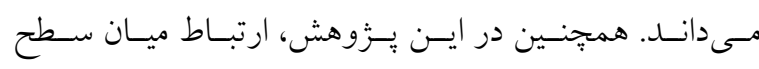

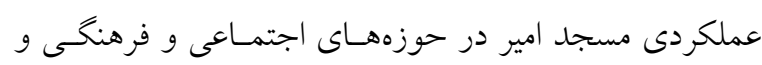

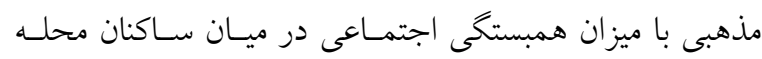

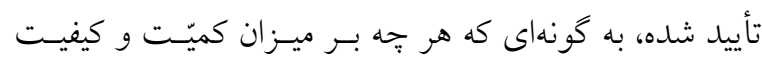

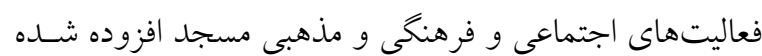

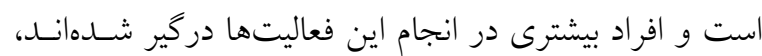

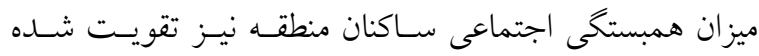

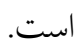

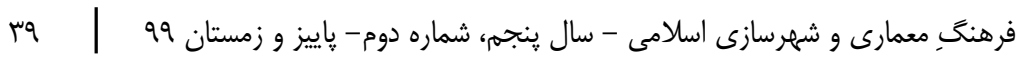


جدول (: كاركرد مسجد در

Table1: The function of the mosque in different time periods (Shayegan 2010)

\begin{tabular}{|c|c|c|c|c|}
\hline 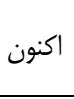 & صدر اسلام & \multicolumn{3}{|c|}{ 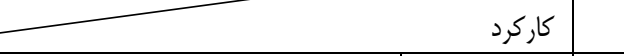 } \\
\hline+ & + & 1- نماز جماعت & \multirow{3}{*}{ 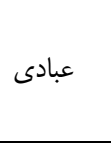 } & \multirow{3}{*}{1} \\
\hline+ & + & r- برگزارى مراسم دعا & & \\
\hline+ & + & بـ بر كزارى جلسات سخنرانى & & \\
\hline+ & + & 1- بليغ دين & \multirow{4}{*}{ فرهنى آمزشى } & \multirow{4}{*}{ t } \\
\hline+ & + & r- كلاس هاى سواد آموزى & & \\
\hline+ & - & r- كلاسهاى هنرى و ورزشى & & \\
\hline+ & - & F- بركزارى اردوهاى سياحتى - زيارتى & & \\
\hline- & + & 1- قضاوت & \multirow{7}{*}{ اجتماعى سياسى } & \multirow{7}{*}{$r$} \\
\hline+ & + & r- بيعت و رأى گيرى & & \\
\hline+ & - & " - بركزارى مراسم ختم & & \\
\hline+ & + & זَ- امر به معروف و نهى از منكر & & \\
\hline+ & + & 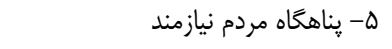 & & \\
\hline- & + & צ- مذاكرات سياسى & & \\
\hline+ & + & V- - مكانى براى مشورت افراد اجتماع & & \\
\hline+ & + & 1 - كمك بلاعوض به مردم نيازمند & \multirow{3}{*}{ اقتصادى } & \multirow{3}{*}{ r } \\
\hline+ & - & r- تشكيل تعاونى هاى مصرف محلى & & \\
\hline+ & - & r- تشكيل صندوق قرضالحسنه & & \\
\hline
\end{tabular}

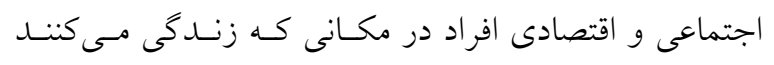
جون نواحى خُرد شهرى بـا طـرح كالبـدى شـامل كـاربرى زمين و تسهيلات زيربنايى در اين اجتماع مورد توجه استـ

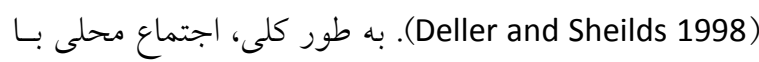
سه عنصر به صسورت زيـر تعريـف مسىشـود ( Green and

:(Haines 2002

$$
\text { مكان (محدوده، ناحيه، نواحى خُردشهرى) }
$$
سازمان يا نهادهاى اجتماع كه تعامل عادى بين

$$
\text { ساكنان را فراهم مى كند. }
$$

تعامل اجتماعى مبتنى بر موضوعات و علائق

$$
\text { مشترك ساكنان }
$$

\section{انغاشت توسعة اجتماع محلى}

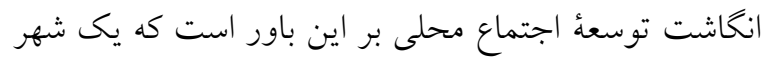

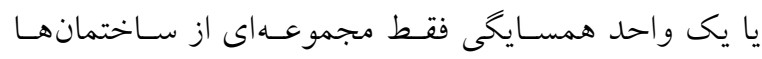
نيست، بلكه اجتماعى از مردم است كه با مشكلات مشـترى

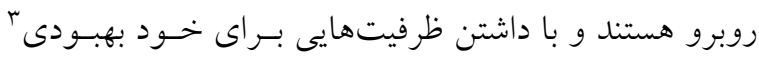
كه هنوز بـى اسـتفاده بـاقى مانـــه اسـت، تـلاش مسى كنــــ.
دارد، فضا و ويزگى ها و تعاملات است. اجتماعات با وجود ارتباطات اعضاى خود موجوديت مى يابند و فقط واحدهاى قلمرويى تلقى نمىشوند، بلكه شامل اتصالات موجود ميـان مردم مىشوند كه منافع مشتركى رادر شبكهاى از ارتباطـات

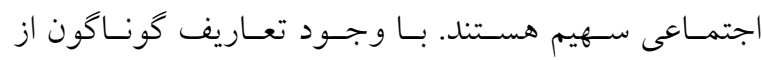
انخاشت اجتماع، اين انخاشت كـه اجتمـاع را افـراد تشـكيل

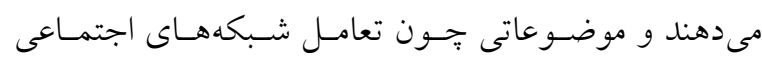

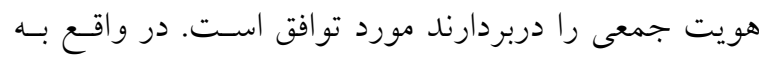

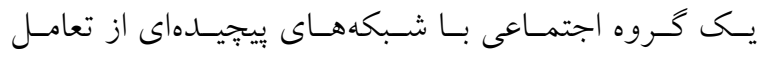
اجتماعى دلالت دارد (2006 Grant). اجتماع محلى نيـز بـه اجتماع مبتنى بر مكان يا محله بـهـ مثابـه انگاشـت سـنتى در

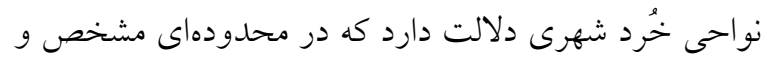
متمايز دور يـك سـكونتخاه يـا ناحيـهاى بــا افـرادى كـه در مجاورت هم زندگى مى كنند و تعاملاتى رو در رو بر اساس نزديكى سكونت دارند، ايجاد شده است. اجتماع محلى، بـه مثابه موجوديت جمعى شامل افرادى با ويزگگ هاى گوناگون

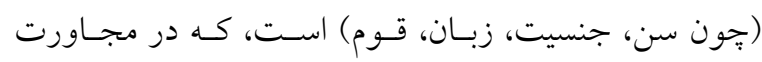

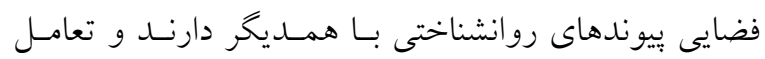


واكاوى نقش نهادهاى مذهب بايه در توسعل اجتماع محلهاى

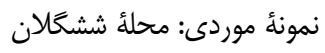

همكارى كـردن و دركيــ شــن در يـك فعاليـت، مشـاركت

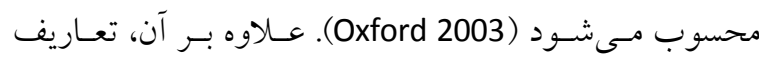
متعددى هم در حوزههاى مختلف علوم اجتماعى از مشاركت

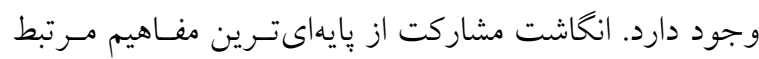

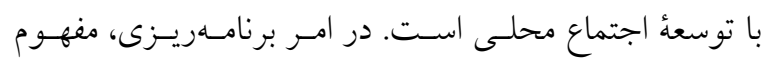

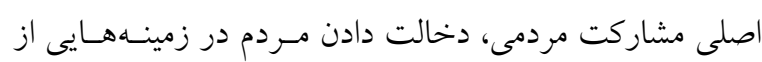

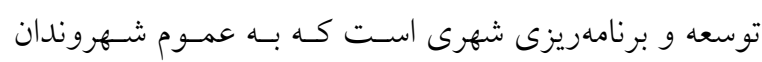

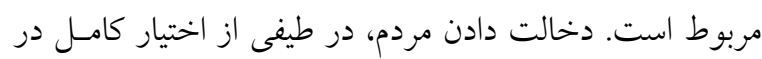

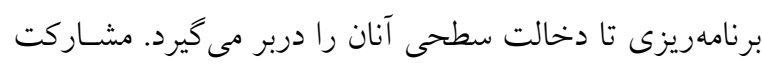

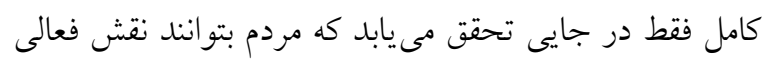

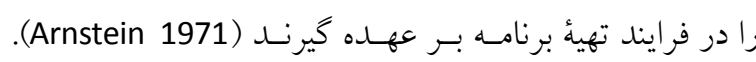

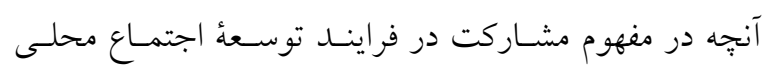

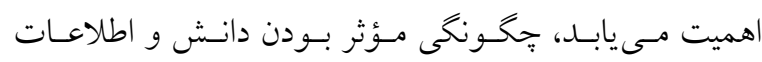

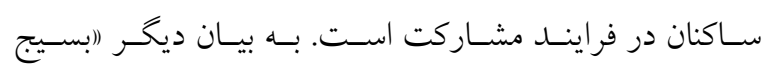

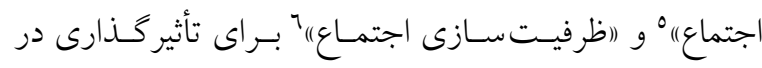

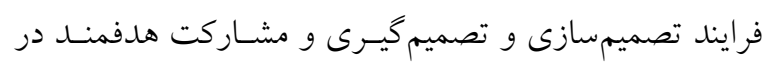

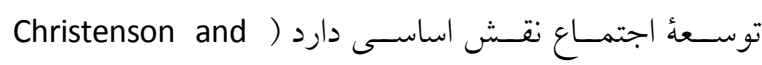

.(Robinson 1989

\section{احساس تعلق به محله}

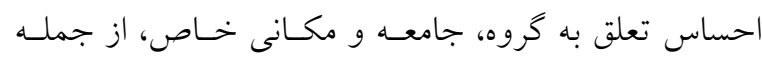

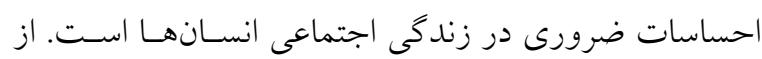

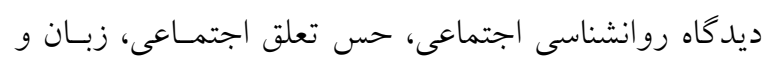

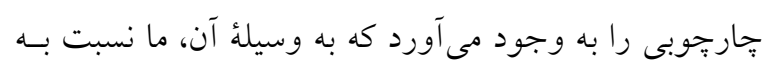

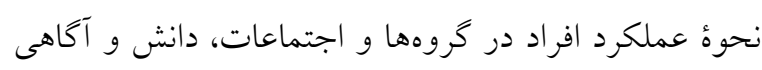

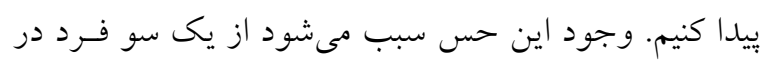

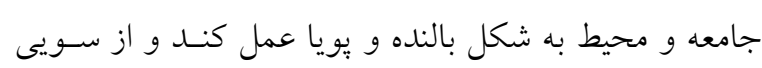

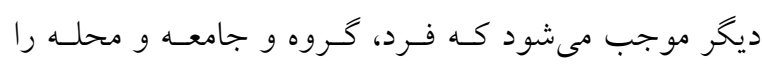

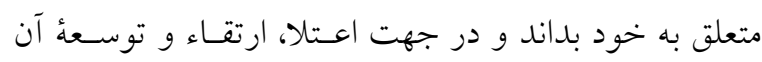

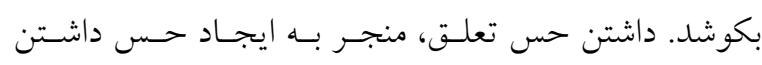

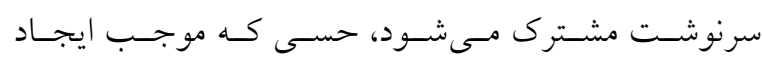

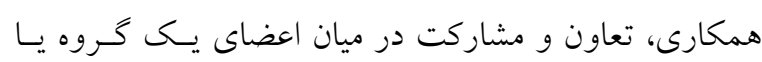

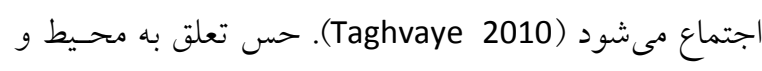

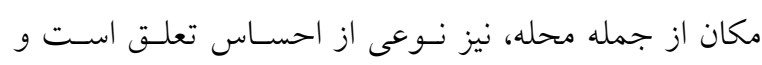

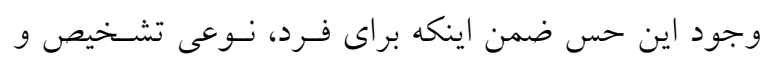

تعاريف، ابتدا به افراد و ارتباط آنها و سبس به مكـانهـاى

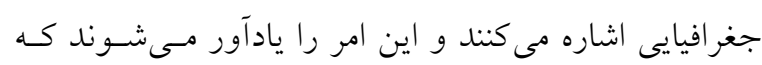

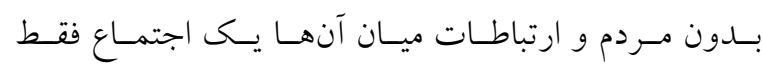

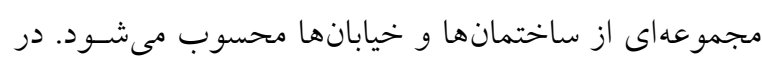

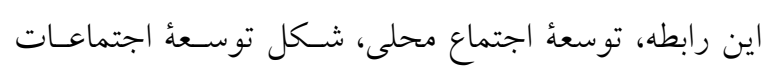

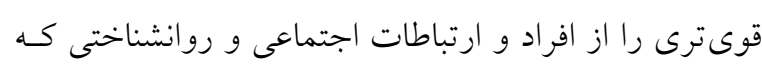

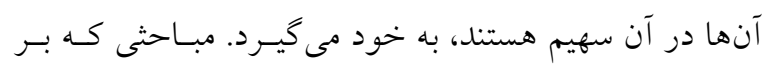

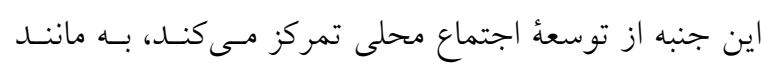

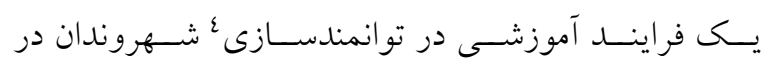

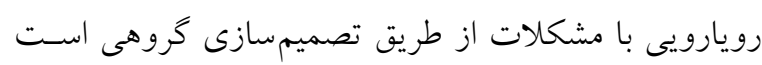

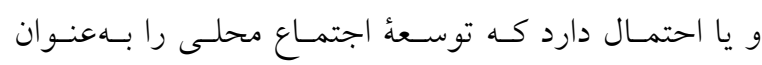

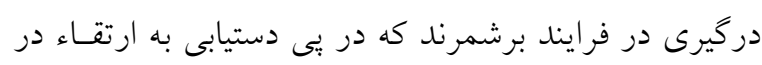

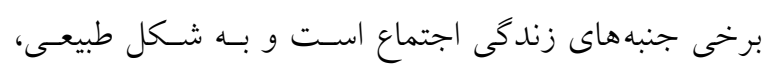

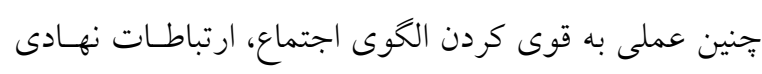

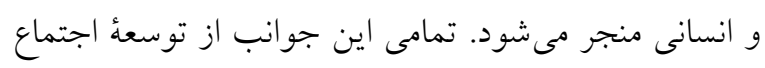

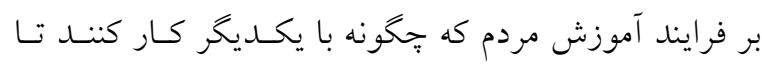

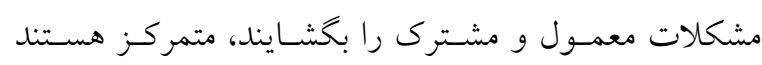

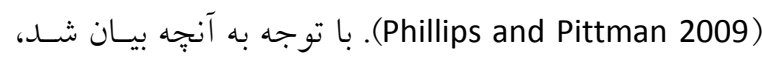

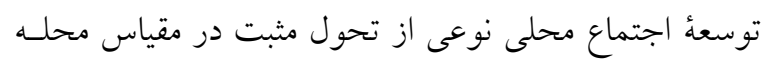

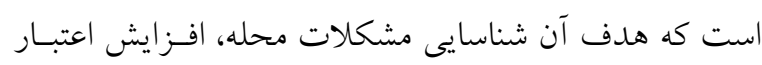

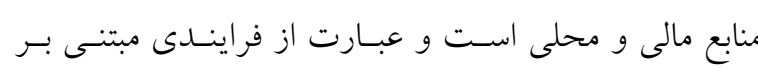

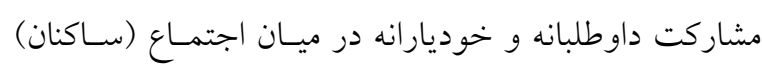

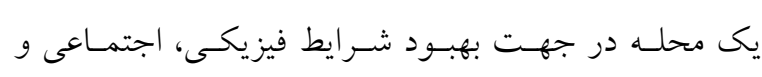

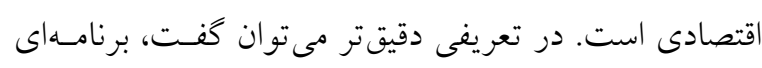

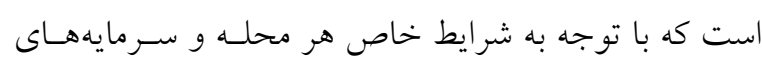

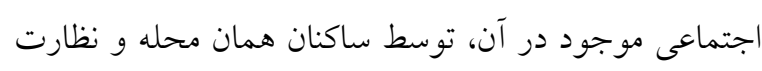

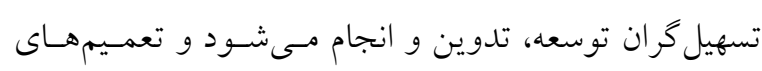

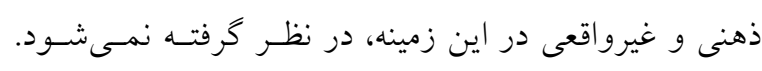

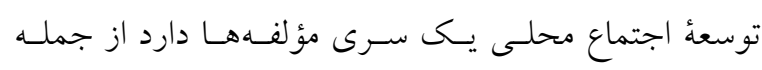

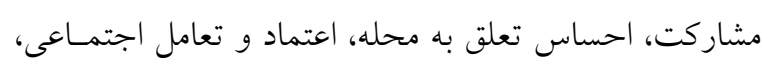
كه در زير آمدهاند (Grant 2006).

\section{انتخاشت مشار كت}

مشاركت در معناى لغوى آن، السهمى در جيزى غيـــ از خــود

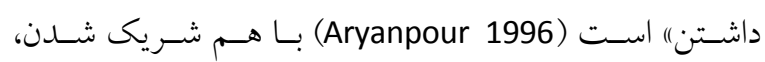

فرهنحِ معمارى و شهرسازى اسلامى - سال ينجم، شماره دوم- پاييز و زمستان 99 | 


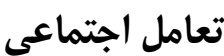

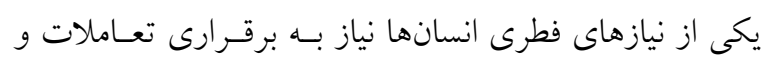

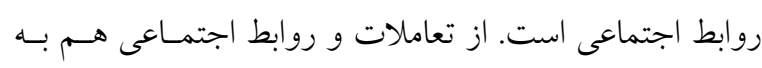

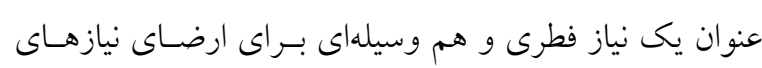

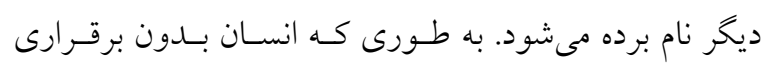

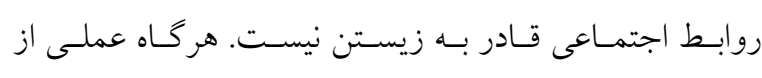

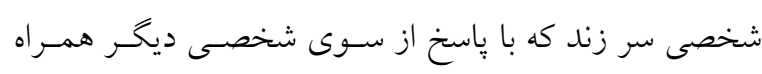

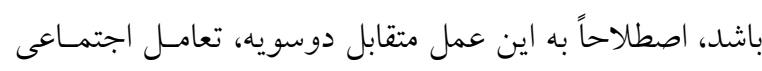

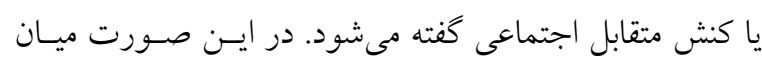

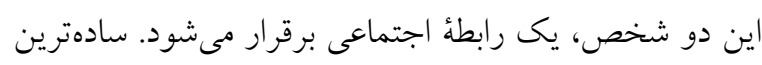

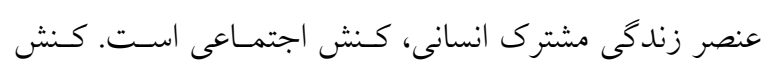

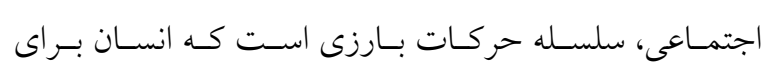

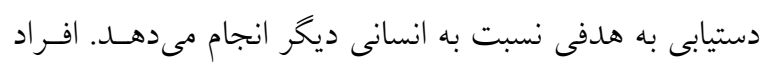

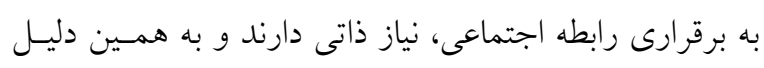

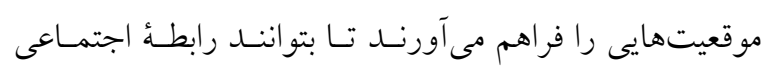

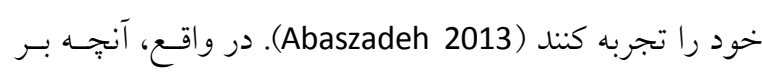

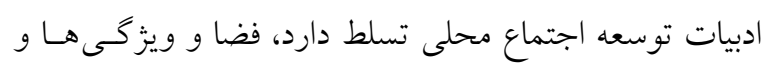

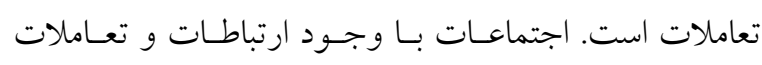

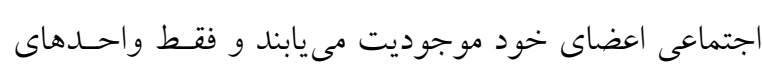
قلمرويى تلقى نمى شوند، بلكه شامل اتصـالات موجـود مئسيان

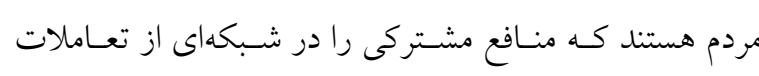
اجتماعى سهيم مىشوند (Grant 2006).

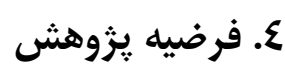

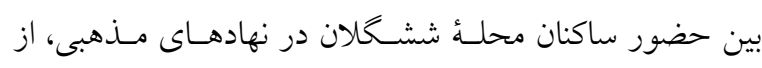

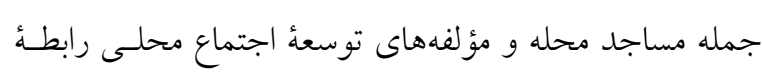
معنادارى وجود دارد.

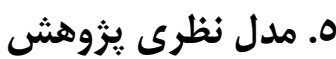

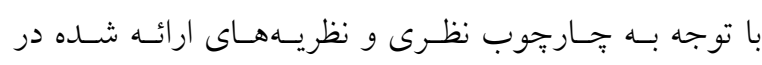

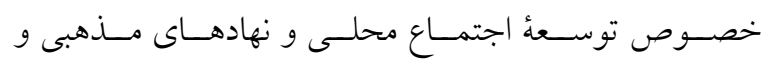

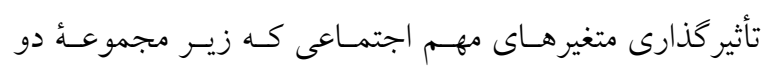

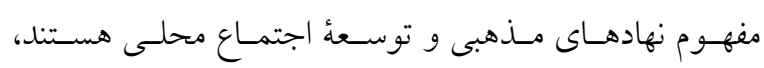

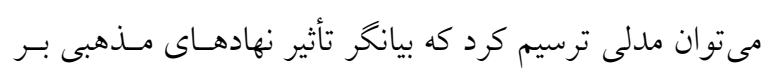

بالندكى را به همـراه دارد، سـبب مسى شـود كـه سـاكنان در

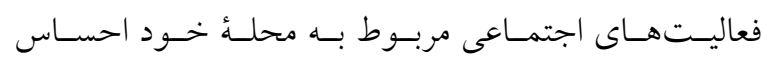

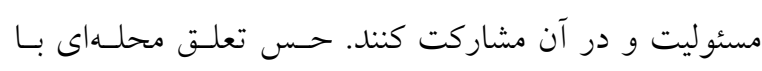

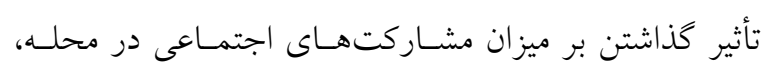

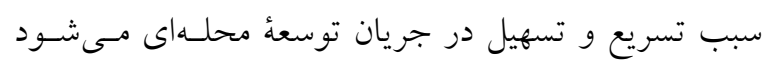

.(Mousavi 2008)

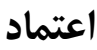

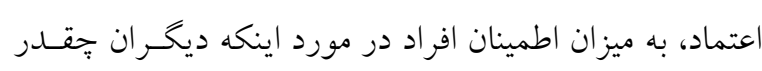

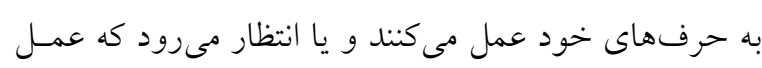

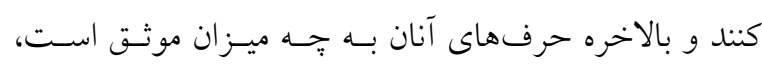

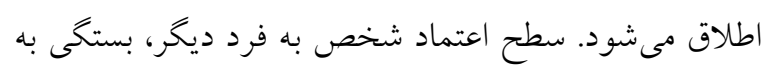

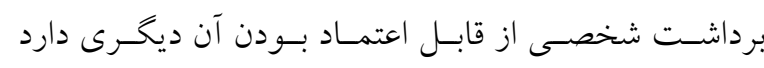

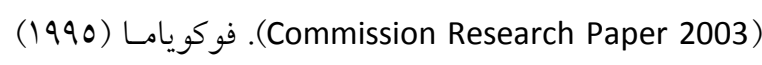

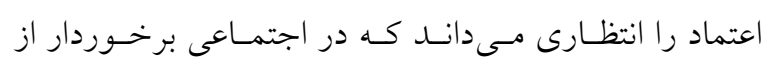

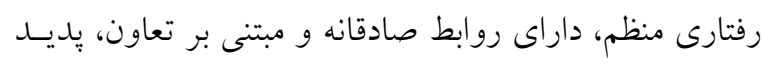

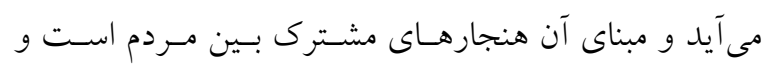

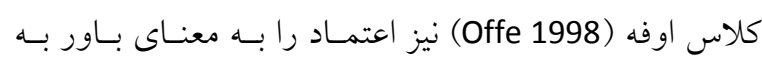

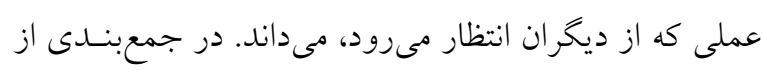

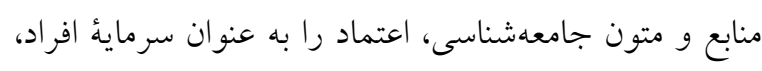

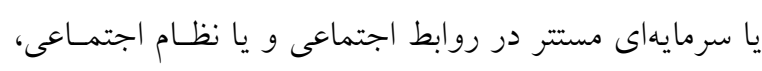

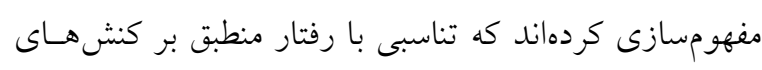

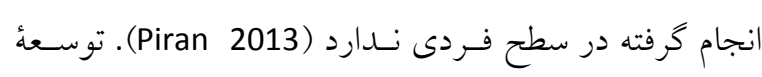

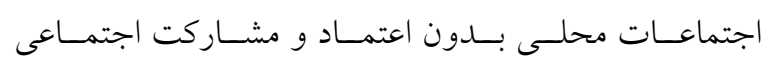

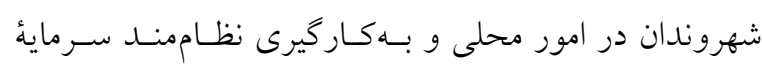

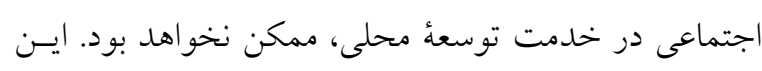

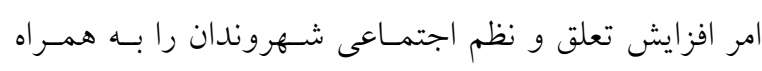

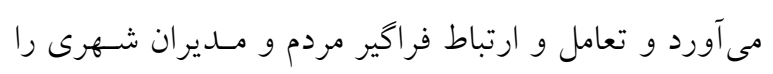

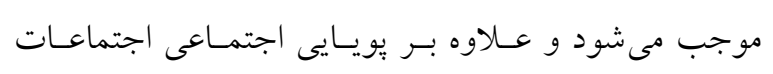

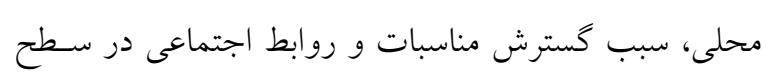

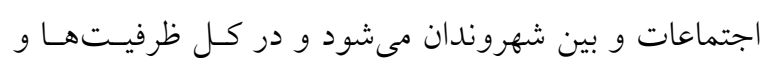

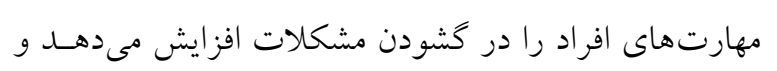

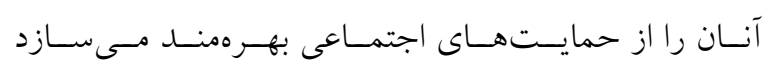

.(Molahassani 2006) 
واكاوى نقش نهادهاى مذهب بايه در توسعل اجتماع محلهاى

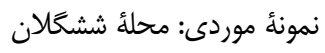

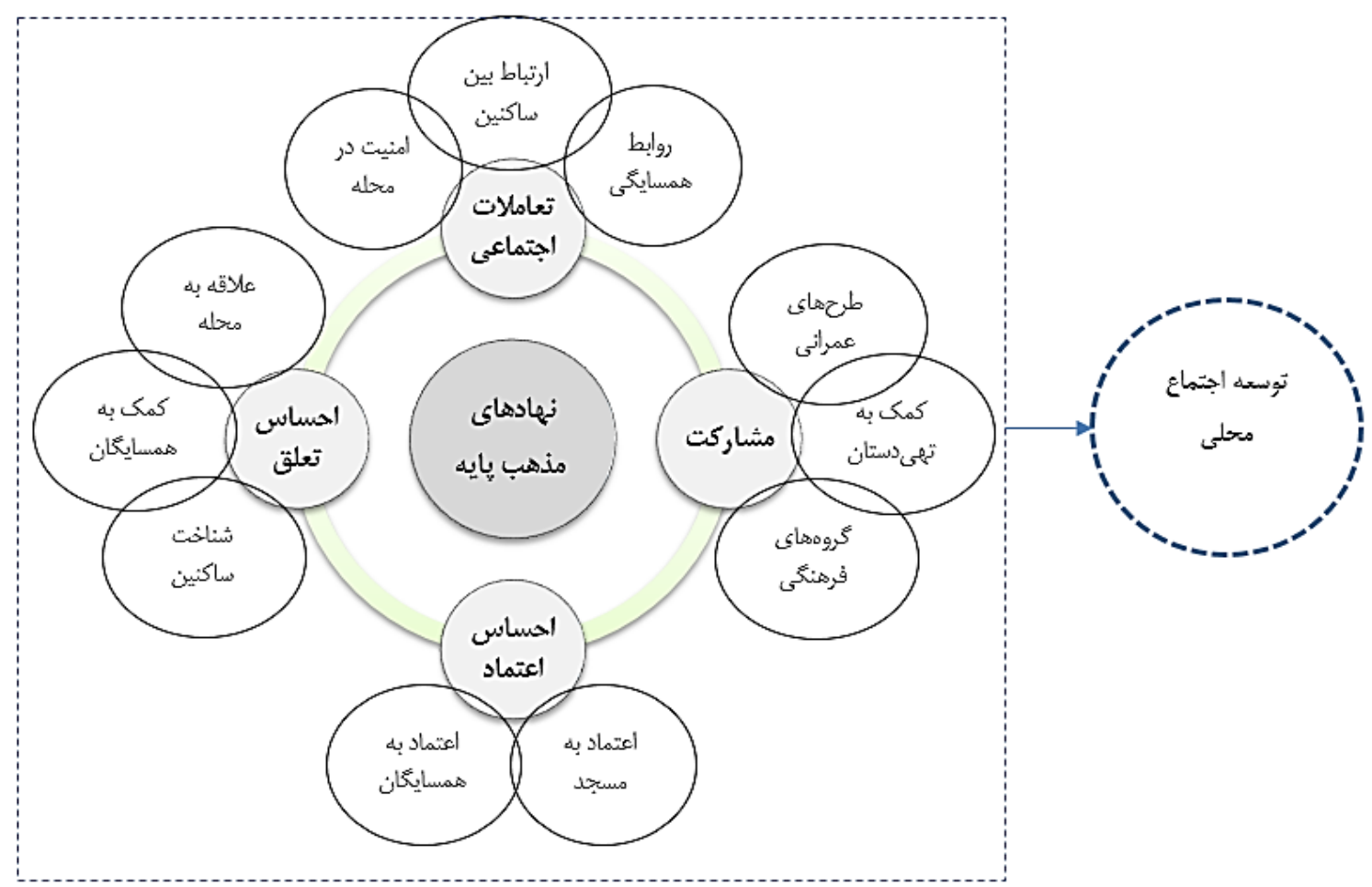

تصوير ا: مدل مفهومى يزوهش

Fig.1: Conceptual model of research

جمع آورى اطلاعات مربوط بـه ادبيـات و جــارجوب نظـرى

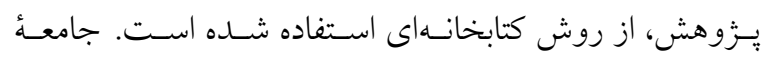

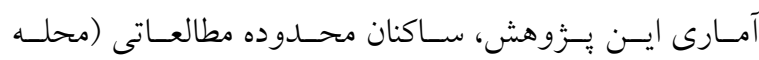

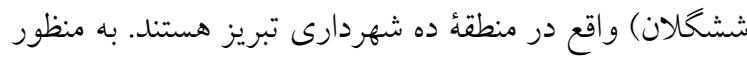
تعيين حجم نمونه، از روش كوكران استفاده شده است. تعـداد

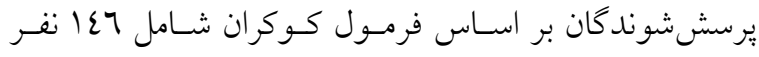

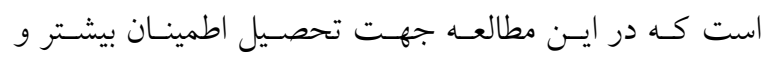

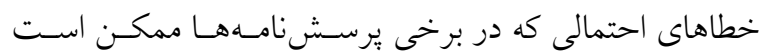

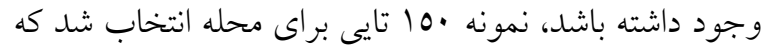

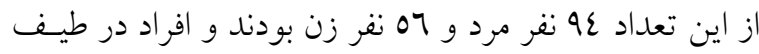

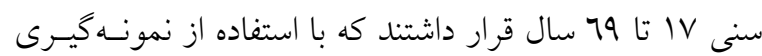
تصادفى، انتخاب شدند.

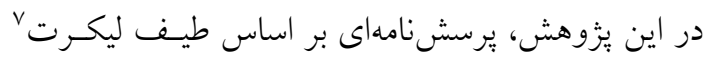

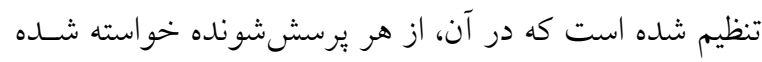

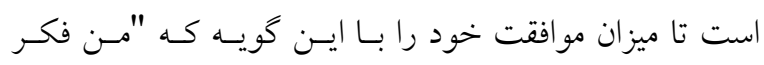

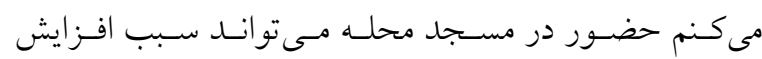

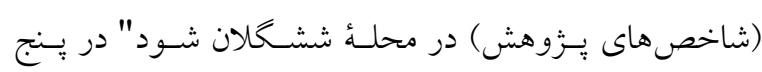

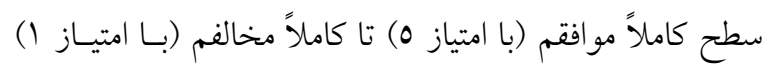

توسعة اجتماع محلى باشد. ادبيات موضوعى ي-رزوهش، نشـان

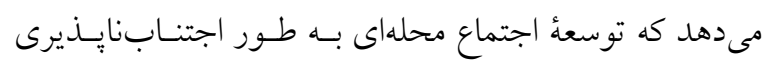

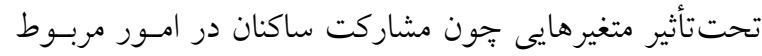

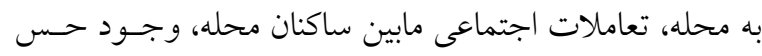
اعتماد مابين ساكنان محله و احساس تعلق ساكنان نسـبت بـه

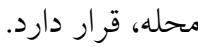
مدل مفهومى يـروهش را بــر اسـاس ادبيـات موضـوع، مىتوان به شرح زير ترسيم كرد. 7. - إوش يزوهش رويكرد حاكم بر بززوهش، رويكردى توصيفى - تحليلى اسـت.

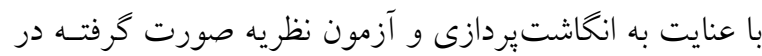

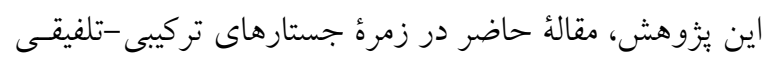

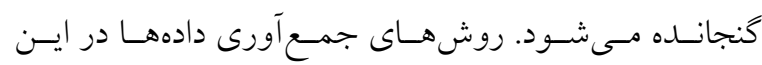
يزّوهش، به دو دستهُ اصلى، روش كتابخانهاى و روش ميدانى روسي

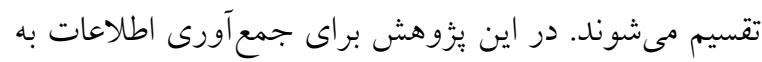

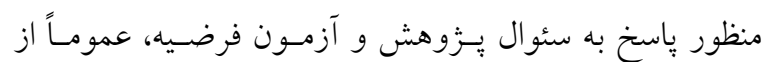

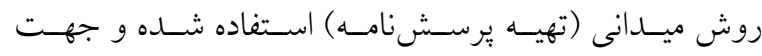



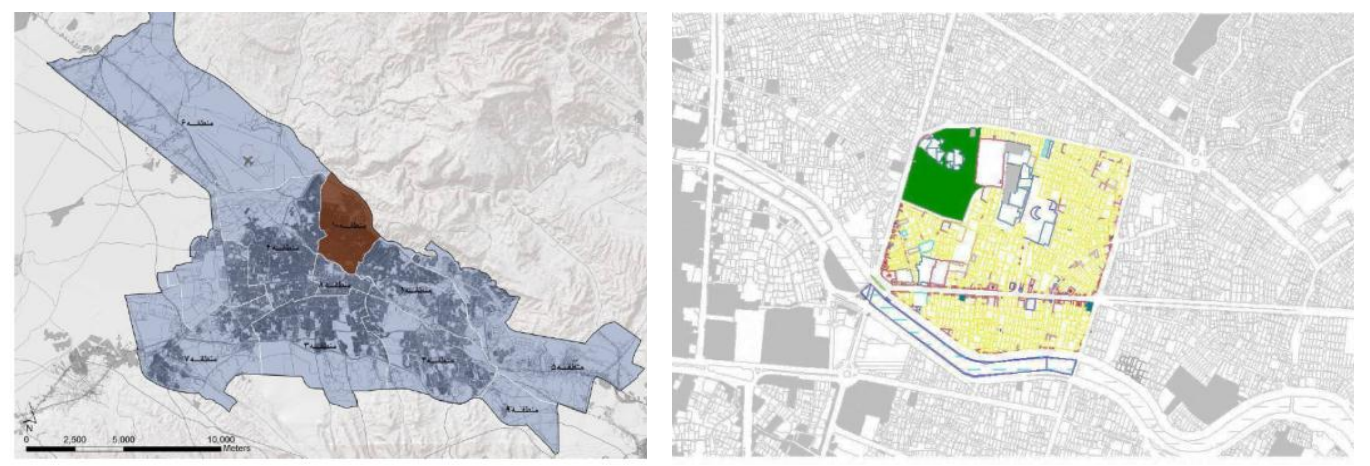

تصوير r: محلة ششخان در منطقة ده شهردارى تبريز

Fig. 2: Sheshgalan neighborhood in district 10 of Tabriz municipality (Naghshe Mohit Consultee 2012)

جنوب به خيابان فارابى، از شرق به خيابان بهشتى و از غـرب به خيابان ثقهالاسلام محدود شـده اسـت. كـاربرى غالـب در محدودة مطالعـاتى، كـاربرى مسـكونى و در اولويست بعـدى كاربرى تجارى - خدماتى است، اما با اين وجود كاربرىهاى فرهنخى و مذهبى نيـز بـهـ عنـوان كـاربرىهـاى شـاخص در محدودة مورد مطالعه، حضور دارند. ششخالان شـش مسـجد دارد كه معروفترين آن مسجد سيد حمـزه اسـت كـه در كنـار بقعهُ مباركه سيد حمزه، نهادى مذهبى را تشكيل مىدهنــ كـهـ

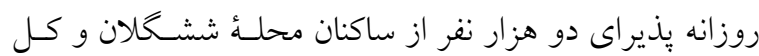
شهر تبريز است.

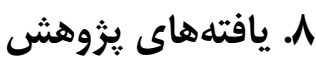
خصيصههاى عمومى شركت كندكًان در مطالعهُ آمارى (سكنه

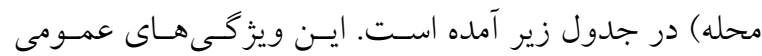

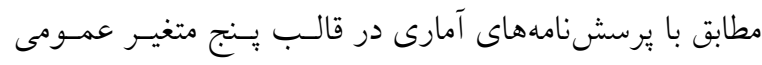

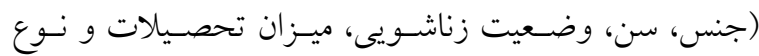

اعلام كند. ميزان مو افقت مخاطبان با هر كويه، به منزلهُ ميـزان اهميت و نقـش نهادهــاى مـذهبى در افـزايش شـاخص هــاى مربوط به توسعأ اجتماع محلى است.

V. قلمرو مكانى يزوهش

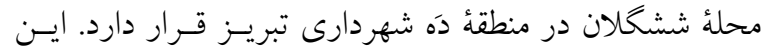

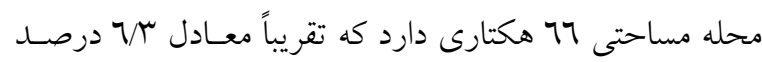

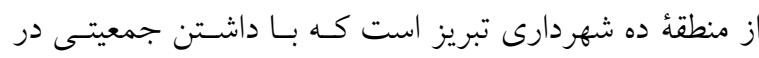

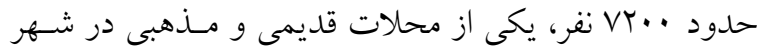
تبريز محسوب مى شود. محلة ششـحالان از سـمت شـمال بـهـ

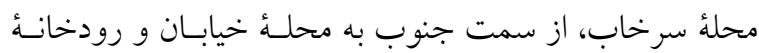
مهرانرود، از سمت شرق به محله هاى يل سـنخى و سـيلاب و از سمت غربب به محلههـاى سـرخاب و حسرمخانـه محــدود

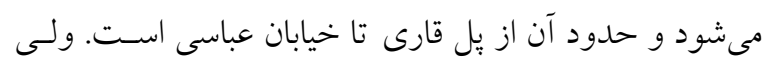
در وضع موجود به دليل خيابانكشى هاى انجـام شـده حسـود

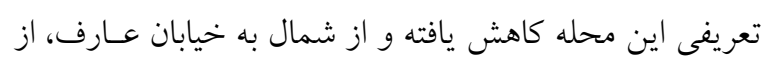

جدول r: مشخصات عمومى برسش شوندكان

Table 2: General details of the respondents

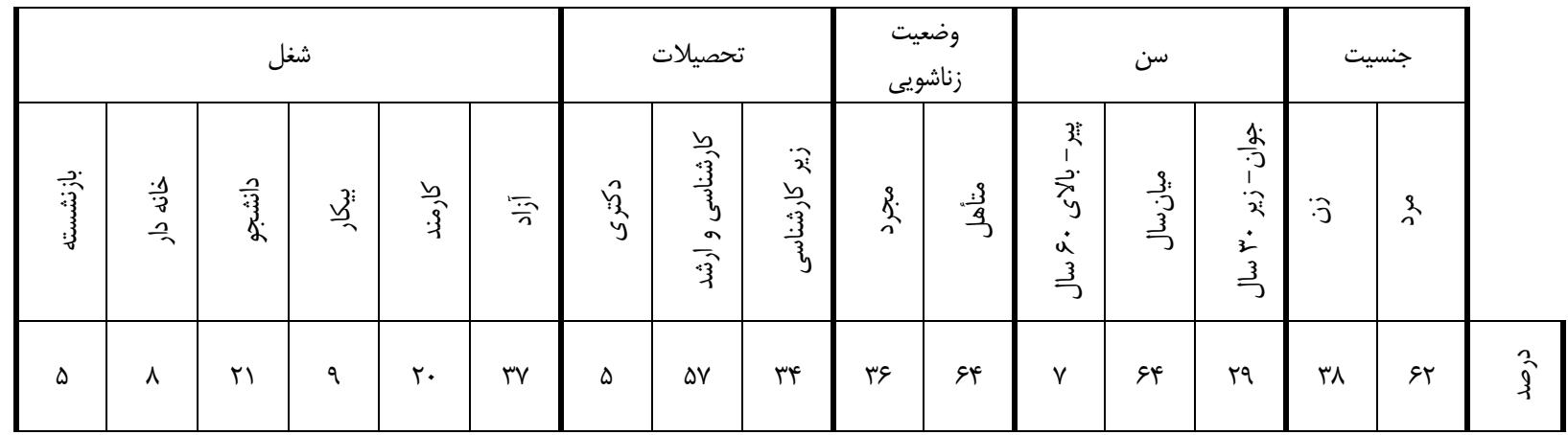


واكاوى نقش نهادهاى مذهب بايه در توسعل اجتماع محلهاى

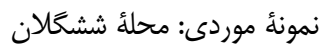

جدول سا: ميزان تاثير گذارى نهادهاى مذهبى در افزايش حس اعتماد

Table 3: The effectiveness of religious institutions in increasing the sense of trust

\begin{tabular}{|c|c|c|c|c|c|c|}
\hline امتياز & مخاملاً & مخالفم & بى نظر & موافقم & ماملاً & \\
\hline שTH & $\wedge$ & r. & et & DI & rq & من فكر مى كنم حضور در مساجد سبب افزايش احساس اعتماد به يكديگر (هم محلهها) در \\
\hline DTE & V & 10 & iv & $\Delta V$ & $M^{C}$ & من فكر مى كنم حضور در مساجد سبب افزايش احساس اعتماد به نمادهاى مذهبى تأثير كذار \\
\hline DrQ & & & & & & ميانگين امتياز \\
\hline
\end{tabular}

دارند به طورى كه ع 7 درصد يرسششوند

شغل) بررسى شدهاند.

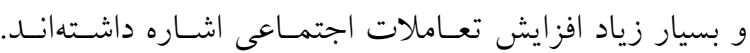

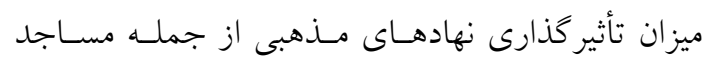

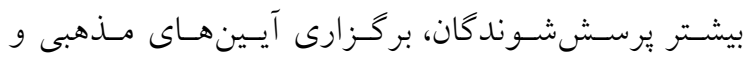

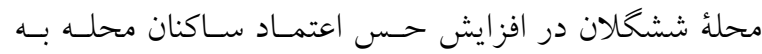

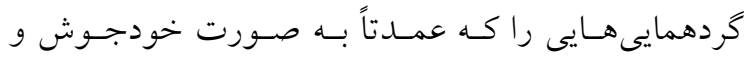
يكديخر در جدول ذيل آمده است. همانطورى كـه ملاحظه. غير رسمى در قالب بريايى نمازهاى يوميه، بركزارى مراسـم مىشود ميزان تأثير كذارى نهادهاى مذهبى بر افزايش حسى هـ عزادارى، اعياد و جشنهاى مذهبى در مساجد محله انجـام

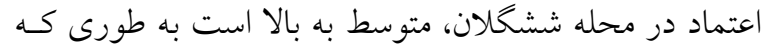

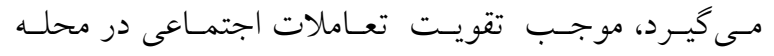

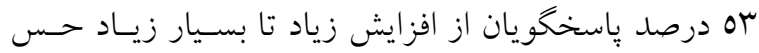
ششخلان مى دانستند.

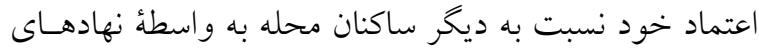

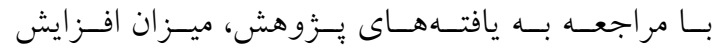

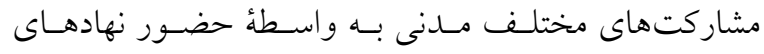

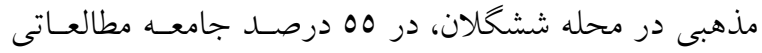

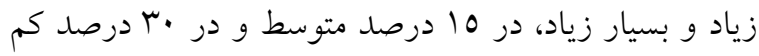

$$
\text { و خيلى كم بوده است (جدول شماره 0). }
$$
مذهبى موجود در محله سخن كفتهاند. نكتئ قابل توجـه كـهـ در مصاحبه با برسششوندكان مشخص شد ايـن اسـت كـه

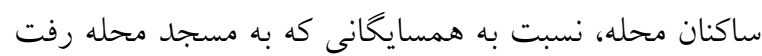

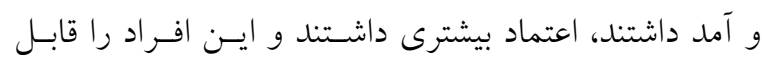

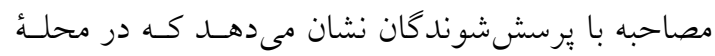

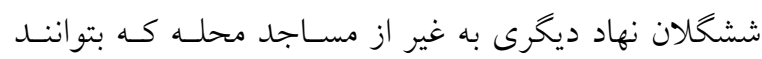

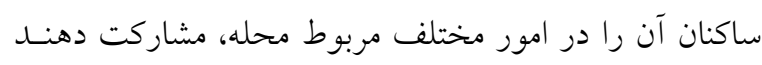

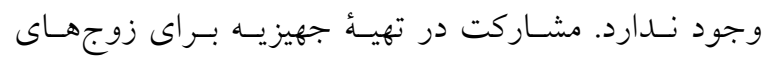

$$
\text { اعتمادتر مى دانستند. }
$$

ميزان افزايش تعاملات اجتماعى در بسين سـاكنان محلـه

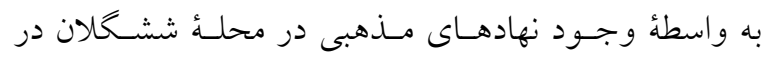

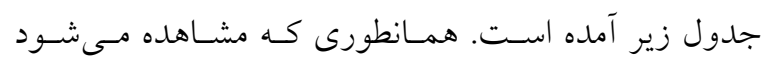

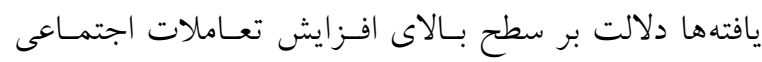

جدول f: ميزان تأثير كذارى نهادهاى مذهبى در افزايش تعاملات اجتماعى

\begin{tabular}{|c|c|c|c|c|c|c|}
\hline امتياز & كخاملا & 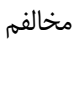 & بى نظر & 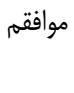 & كاملا & \\
\hline D\&q & $\wedge$ & سז & rr & $\Delta F$ & et & من فكر مى كنم حضور در مساجد سبب افزايش ارتباط بين ساكنان محله ششگلان مىشود. \\
\hline DrA & 1 . & re & ו & is & r $\mathrm{V}$ & من فكر مى كنم حضور در مساجد سبب افزايش امنيت در محله ششعلان مىشود. \\
\hline DIS & M & r. & rq & fit & rq & من فكر مى كنم حضور در مساجد سبب بهبود روابط همسايكى در محله ششخلان مىشود. \\
\hline هI & & & & & & ميانگیين امتياز \\
\hline
\end{tabular}

Table 4: The effectiveness of religious institutions in increasing social interactions 
جدول ه: ميزان تأثير كذارى نهادهاى مذهبى در افزايش مشاركتهاى مدنى

Table 5: The effectiveness of religious institutions in increasing civic participation

\begin{tabular}{|c|c|c|c|c|c|c|}
\hline امتياز & مخاملا & مخالفم & بى نظر & موافقم & موافلا & \\
\hline DIT & 14 & ו & tr & Fa & r & من فكر مى كنم حضور در مساجد سبب شركت در گروههاى فرهنكى و مذهبى محله \\
\hline זAN & te & Tr & ra & f. & re & من فكر مى كنم حضور در مساجد سبب مشاركت در كمى به فقرا و تهىدستان در محله \\
\hline PVT & צ & זr & זr & rq & rq & من فكر مى كنم حضور در مساجد سبب مشاركت در طرحهاى عمرانى مربوط به محله \\
\hline $1 \wedge 9$ & & & & & & ميانكَين امتياز \\
\hline
\end{tabular}

\section{9. تجزيه و تحليل يافتهها و آزمون فرضيه}

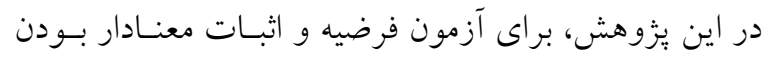
رابطةُ بين حضور در نهادهاى مذهبى و متغيرهـاى يـرَوهش

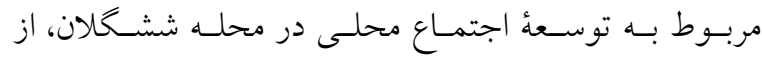
ضريب هماهنكى كندال و ضـريب اسـبيرمن اسـتفاده شـده

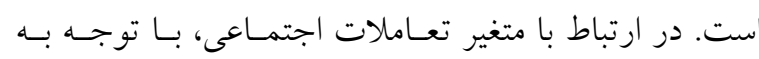
ضريب كندال محاسبه شده (ع (V/•)، بين دو متغيـر حضـور

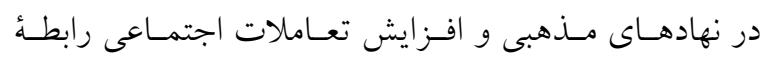
معنادار وجود دارد. ضريب همبستخى اسبيرمن (0.78=Rho) نيز اين رابطه را تأييد مى كند. بنابراين، هر جهه ميزان حضـور

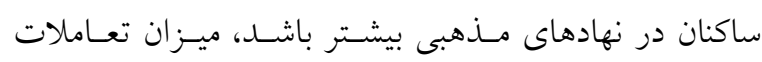
اجتماعى نيز افزايش مى يابد. در ارتباط با متغير مشاركت اجتمـاعى، ضـريب كنـدال

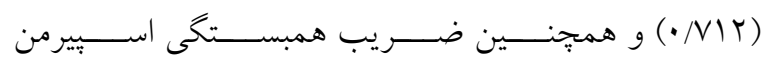
(0.74=Rho) خطاى 0 درصد، معنادار بودن رابطة بين دو متغير حضور در

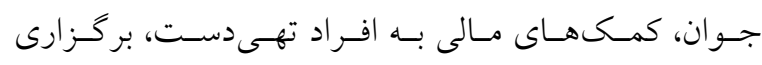

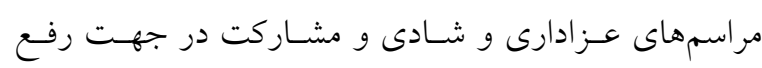
مشـكلات محلـه از مـواردى اسـت كـه در مســاجد محلـه

$$
\text { ششخان صورت مى گيرد. }
$$

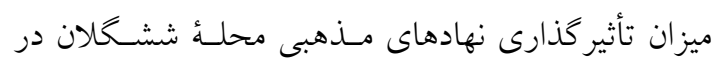
افزايش احساس تعلق به محله، در بين ساكنان آن در جدول ذيل آملده است. همانطورى كـه ملاحظـه مسى شـود، ميـزان افزايش احساس تعلق بـه محلـه ششـحالان در بـين سـاكنان

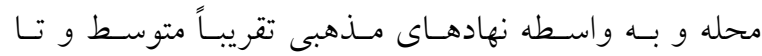
حدودى رو به زياد بوده است. احساس تعلق نسبت به محله در بين برسـش بــوند ركان

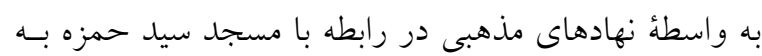

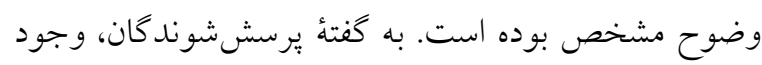

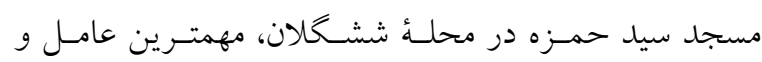
نشانهاى است كه سبب مىشـود ايسن محلـه بـهـ واسـطة آنه براى ساكنان ديخر محالات شناخته شده باشد.

$$
\text { جدول و: ميزان تأثير كذارى نهادهاى مذهبى در افزايش احساس تعلق به محله }
$$

\begin{tabular}{|c|c|c|c|c|c|c|}
\hline امتياز & كخاملا & مخالفم & بى نظر & 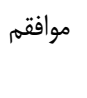 & كواملا & \\
\hline erı & 11 & rq & ه) & rq & r. & من فكر مى كنم حضور در مساجد سبب شناخت افراد بيشترى از ساكنان محله ششكلان مىشود. \\
\hline cqv & 14 & 10 & $\Delta \Gamma$ & \& & tr & من فكر مى كنم حضور در مساجد محله ششعالان سبب افزايش علاقه به اين محله مىشود. \\
\hline$\Delta \Delta \cdot$ & $\Delta$ & 19 & ع & q. & سب & من فكر مى كنم حضور در مساجد سبب افزايش كمك به همنوعان در محله ششعالان مىشود. \\
\hline$\Delta \cdot \Lambda$ & & & & & & ميانگين امتياز \\
\hline
\end{tabular}

Table 6: The effectiveness of religious institutions in increasing the sense of belonging to the neighborhood 
واكاوى نقش نهادهاى مذهب پايه در توسعأ اجتماع محلهاى

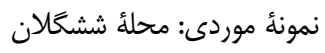

جدول V: برسى رابطه بين مؤلفه تعاملات اجتماعى و نهادهاى مذهبى

Table 7: Investigating the relationship between the component of social interactions and religious institutions

\begin{tabular}{|c|c|c|}
\hline & نهادهاى مذهبى & تعاملات اجتماعى \\
\hline Correlation coefficient نهادهاى مذهبى tau_b Kendall's & 1 & $* *, \mathrm{VHF}$ \\
\hline Sig. (2-tailed) & • & $\cdot, \cdot 11$ \\
\hline $\mathrm{N}$ & 10 . & \\
\hline تعاملات اجتماعى Correlation coefficient & $* *, \mathrm{VHF}$ & 1 \\
\hline Sig. (2-tailed) & $\cdot, \cdot 11$ & . \\
\hline $\mathrm{N}$ & & 10 . \\
\hline
\end{tabular}

جدول م: بررسى رابطه بين مؤلفه مشار كت اجتماعى و نهادهاى مذهبى

Table 8: Investigating the relationship between the component of social participation and religious institutions

\begin{tabular}{|c|c|c|}
\hline & نهادهاى مذهبى & مشار كت اجتماعى \\
\hline Correlation coefficient نهادهاى مذهبى tau_b Kendall's & 1 & $* *$, VIr \\
\hline Sig. (2-tailed) & - & $\cdot,+41$ \\
\hline $\mathrm{N}$ & 10 . & \\
\hline Correlation coefficient مشاركت اجتماعى & **, VIr & 1 \\
\hline Sig. (2-tailed) & $\cdot,+41$. & • \\
\hline
\end{tabular}

N

10.

نتايج حاصل از آزمون كندال براى سنجش معنادارى بين نهادهاى مذهبى محله و مشاركت اجتماعى را نشان مىدهد.

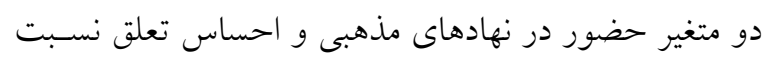
نتايج حاصل از آزمون كندال براى سنجش معنادارى بين

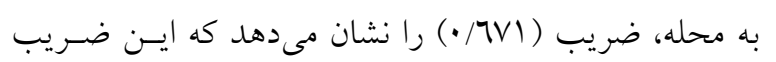
دو متغير حضور در نهادهاى مذهبى و افزايش حسس اعتمـاد

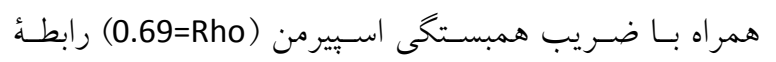

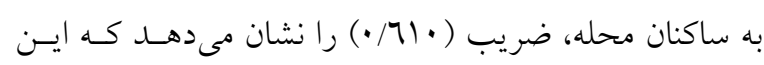
مستقيم و معنادار بين اين دو متغير را تأييد مى كند.

ضريب همراه با ضـريب همبسـتخى اسـيبرمن (0.65=Rho) رابطة مستقيم و معنادار بين اين دو متغير را تأييد مى كند.

جدول 9: بررسى رابطه بين مؤلفه حس اعتماد و نهادهاى مذهبى

Table 9: Investigating the relationship between the component of trust and religious institutions

\begin{tabular}{|c|c|c|}
\hline & 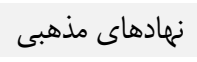 & حس اعتماد \\
\hline Correlation coefficient نهادهاى مذهبى tau_b Kendall's & 1 & $* *, 91$. \\
\hline Sig. (2-tailed) & • & $\cdot, \cdot 4 \mathrm{kt}$ \\
\hline $\mathrm{N}$ & 10 . & \\
\hline حس اعتماد Correlation coefficient & $* *, 91$ & 1 \\
\hline Sig. (2-tailed) & $\cdot,+4$ & • \\
\hline $\mathrm{N}$ & & 10 \\
\hline
\end{tabular}

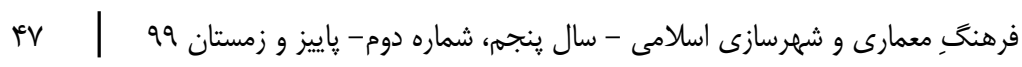


جدول • ا: بررسى رابطه بين مؤلفه احساس تعلق و نهادهاى مذهبى

Table 10: Investigating the relationship between the sense of belonging component and religious institutions

\begin{tabular}{|c|c|c|}
\hline & 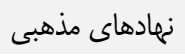 & احساس تعلق \\
\hline Correlation coefficient نهادهاى مذهبى tau_b Kendall's & 1 & $* * .9 \mathrm{~V}$ \\
\hline Sig. (2-tailed) & • & 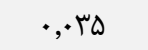 \\
\hline $\mathrm{N}$ & 10 . & \\
\hline احساس تعلق Correlation coefficient & $* * .9 \mathrm{~V}$ & 1 \\
\hline Sig. (2-tailed) & $\cdot, \cdot r \Delta$ & . \\
\hline $\mathrm{N}$ & & 10 . \\
\hline
\end{tabular}

\section{نتيجلكيرى}

آن جايى كه يك نهاد مردمى است، كاملاً با موضوع مشاركت، يبيوند و ارتباط دارد و موفقيت و يويايى آن هم در گرو حضور

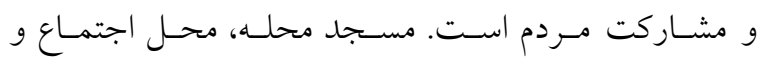
زمينهساز وحدت و همبستخى اقشار مختلف سـاكنان محلـه است. مسجد محله حتى مىتواند به عنوان مسـجد شـورا و نمايندة اجتماع مسـلمانان در محلـه محسـوب شـود و ايـن

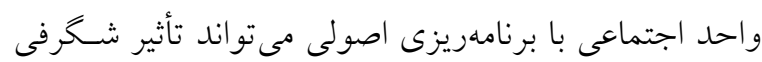

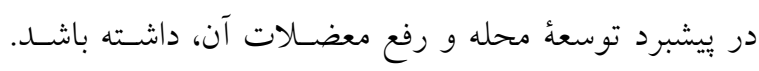
همجينين مسجد، در ايجاد وفاق و همدلى و ايجاد تعـاملات اجتماعى در بين ساكنان محلات، براى فراهمسـازى فضـاى

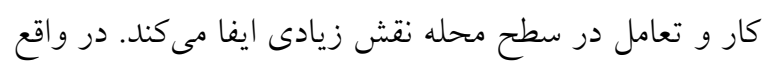
همت عمومى در سطح محالات نيازمند فضاى وحدت رويه

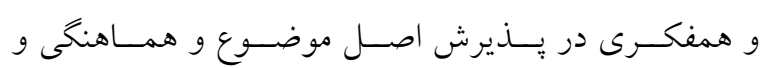
همكارى در عمل و اجراى برنامسههـا و انجـام امسور اسـت.

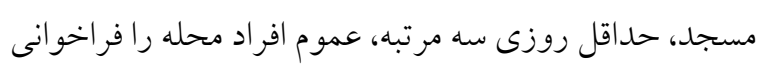

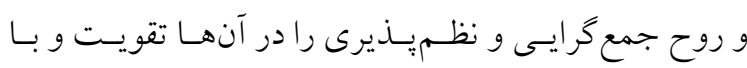

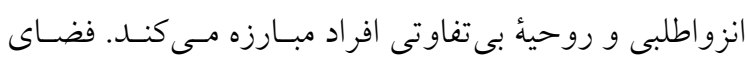
مسجد علاوه بر تشويق روحيهُ همكارى و تحقـق و تشـكيل

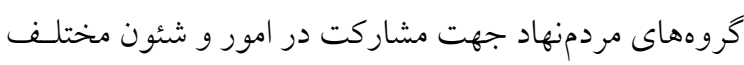

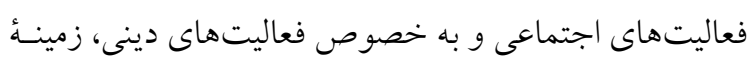
تجربه آن را هم در خود، فراهم اجمى كند.
نهادهـاى مـذهبى و بـهاويـزّه مسـاجد در محـلات شـهرى، نهادهايى هستند كه بـا وجـود اينكـه كمـكهــاى آنهـا در توسعة اجتماع محلى ناملموس است، ميزان خدمات آنها و

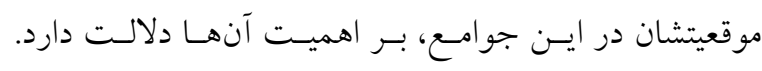
يزّوهش حاضر، بر اين بيش فرض مبتنى بود كه بين حضور

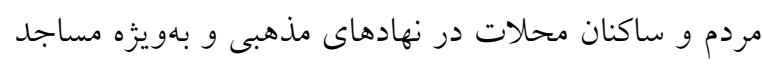

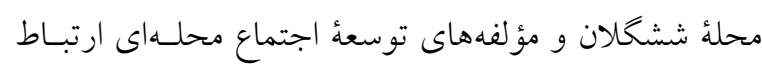

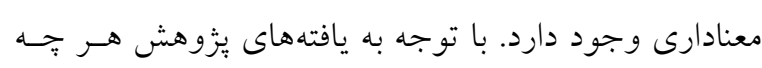

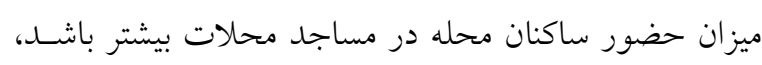

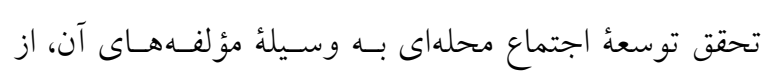
جمله افزايش مشاركت شهروندان، احساس تعلق نسبت بـهـ

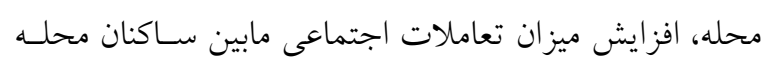

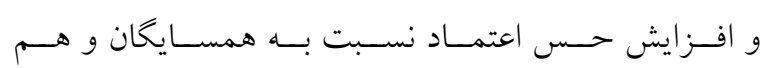
محلهاىهاى خود بيشتر مىشود. نتايج حاصله نشان مىدهد

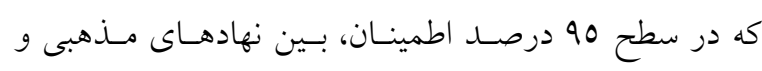

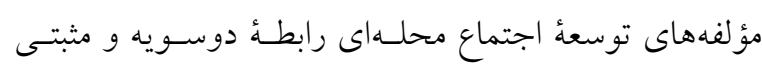
وجود دارد. يافتهها نشان مىدهند كه ارتباط متقابل هرروزه و كـش

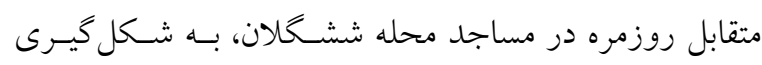

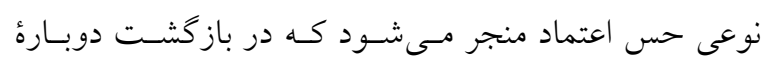
اعتماد و تداوم كنش هاى متقابل تأثير كذار اسـت. مسـجد از 
واكاوى نقش نهادهاى مذهب پايه در توسعأ اجتماع محلهاى

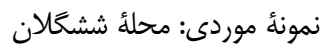

يـىنوشها

1. Bahari

2. Nisha botchwey

3. self improvement

4. empowerment

5. mobilization

6. community capacity building

7. Likert scale

$$
\begin{aligned}
& \text { فهرست منابع } \\
& \text { احمديان، محمدعلى و عرفانيان، سميرا، 90 إ. بررسى نقش مساجد در توسعه محلهاى در شهر مشهد. مجله جغرافيا و توسعه فضاى شهـرى. } \\
& \text { سال دوم، شماره اول: بوهئ-11. }
\end{aligned}
$$

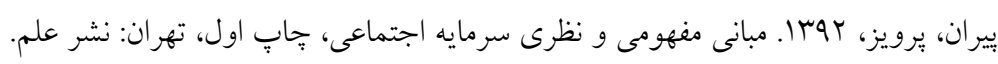

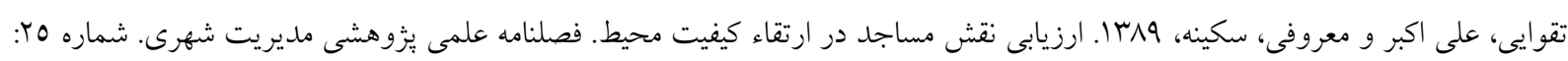

$$
\begin{aligned}
& \text { rMI- } 19 \\
& \text { شايخان، فريبا، 1941 . تبيين جامعهشناختى مشاركت مردم در مساجد. تهران: انتشارات جامعهشناسان. }
\end{aligned}
$$

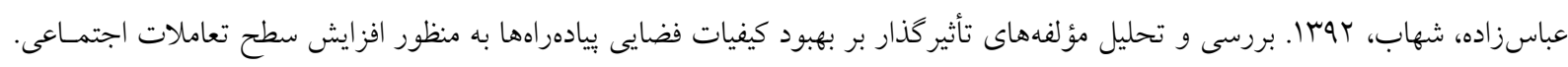

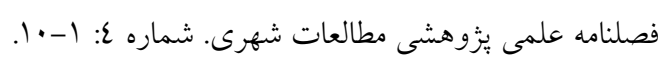

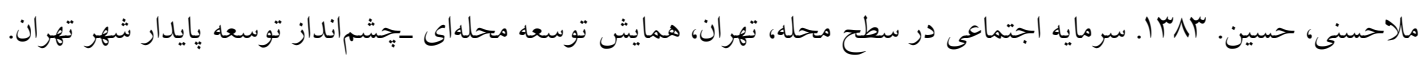

$$
\begin{aligned}
& \text { مهندسين مشاور نقش محيط، الوبا. طرح توسعه و عمران شهر تبريز. جلد جهارم(شناخت شهر). }
\end{aligned}
$$

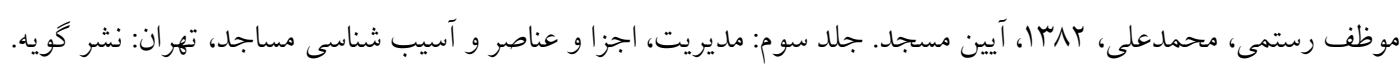

Abaszadeh, SH. 2013. Exploring and Analysing the influential factors on spatial quality improvement of sidewalks in order to enhancing the social interactions, Urban Studies Journal, No. 4, pp. 1-10. [In Persian]

Ahmadian, M. 2015. Exploring the role of mosques in local development in Mashhad city, Geography and urban space development, Vol. 2. Issue 1, pp. 93-110. [In Persian]

Arnstein, Shery.R. 1971. A Ladder of Citizen Participation .Journal of the Royal Town Planning, Vol (2).

Bahari, Ch. 2016. Exploration of the role of mosques in community development: Malaysian experience. 3rd International Conference on Arabic Studies and Islamic Civilization. $422-436$

Botchwey, N. 2005. The Religious Sector Presence in Local Community Development. Journal of planning Education and Reserch 27: 36 - 48

Deller, S.D. and Shields, M. 1998. Economic impact modeling as A Tool for Community Economic Development. Pennsylvania State University: 1-9.

Grant, H. 2006. Planning the Good Community: New Urbanism in Theory and Practice. Routledg: London and Newyork.

Green, G.P and Haines, A. 2002. Asset Building and Community Development. Sage Publications: USA.

Kretzmann, John P., \& McKnight, John L. 1993. Building Communities from the Inside Out: A Path Toward Finding and Mobilizing a Community's Assets. Chicago, IL: ACTA Publications.

Mollahasani, H. 2006. Social capital in neighbourhood scale, Tehran, community development festivals. [In Persian]

Movazaf Rostami, M. 2005. Mosques Tradition, Third Vol.: Management elements and Pathology of Mosques, Gooyeh Publisher, Tehran. [In Persian]

Naghshe Mohit consulter, 2012, master plan of Tabriz, fourth Vol. [In Persian]

Phillips, R and Pittman, R. 2009. An Introduction to Community Development. Routledg: London and Newyork.

Piran, P. 2013. Conceptul and theoretical basics of social capital, Science Publesher, Tehran. [In Persian]

Shayegan, F. 2010. Sociological Explanantion of public participation in mosques, Sociology Publisher, Tehran. [In Persian]

Sullivan, L.H .1998. Moving mountains: the principles and purposes of leon Sullivan. Valley Forge, PA: Judson

Taghvayee, E., Maroufi, S. 2010, Assessment of moques role in improving environment quality, Urban Management Journal, No. 25, pp. 219-231. [In Persian] 